\title{
Effects Of Poorly Implemented Performance Management Systems On The Job Behavior And Performance Of Employees
}

Prakash Singh, Nelson Mandela Metropolitan University, South Africa Thembinkosi Twalo, Human Sciences Research Council, South Africa

\begin{abstract}
The focus of this study is on the effects of a poorly implemented performance management system $(P M S)$ on the job behaviour and performance of employees. In the implementation of a PMS, one of the imperatives is that managers ensure that their employees' outputs are compatible with that of their organizations' goals. The PMS provides vital information on whether the work-integrated learning skills of employees are compatible with the objectives of their organizations. A poorly implemented PMS will fail to motivate an organization's employees, and inevitably their lack of job satisfaction will impact negatively on their self-esteem, productivity levels and outputs. In a poorly implemented PMS as is evident in the findings of this case study, only $8.85 \%$ of the respondents agreed that there is daily monitoring of their jobs to ensure it's done properly. The fact that monitoring and evaluation systems seem to be weak could result in the proliferation of an unproductive workforce. The findings of this case study strongly suggest that a PMS can be the key factor determining whether an organization can manage its human resources effectively. This research affirms that when employees' expectations are not met, inappropriate job behaviour and performance can derail the attainment of an organization's goals. When implemented well, a good PMS would provide critical information that would allow an organization to make sound decisions regarding their human resources. Hence, there should be no room to compromise the use of a well-developed PMS to achieve the strategic plans of any organization.
\end{abstract}

Keywords: Performance Management System; Inappropriate Job Performance; Work-Integrated Learning; Work Ethics

\section{INTRODUCTION}

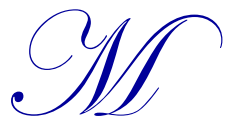

anaging performance is essential for any organization since its primary goal is to create a framework that offers encouragement, support and guidance and helps to establish a performanceorientated culture (Ochurub, Bussin \& Goosen, 2012). Olve, Roy and Wetter (2004) argue that performance management systems (PMSs) create organisational cultures of personal responsibility for business and personal improvement. Aguinis (2005, p. 2) defines performance management (PM) as a "continuous process of identifying, measuring and developing performance in organisations by linking each individual's performance and objectives to the organisation's overall mission and goals". He argues that PM in an organization is ongoing as it involves a never-ending process of setting goals and objectives, observing performance, and giving and receiving ongoing coaching and feedback. Aguinis adds that PM requires that managers ensure that employees' activities and outputs are congruent with their organizations' goals as this would therefore create a direct link between employee performance and organizational goals, and make the employees' contribution to the organization explicit. Holloway (2009) also points out that in all sectors of the economy, employees and their employers can be found learning together about how to change internal performance in the face of ever-more-complex and fast moving environments. $\mathrm{He}$ further states that for many other organizations, it is merely the contemporary manifestation of power relationships which remain, at heart, unequal. Research points out that a PMS improves service delivery through a culture of performance dialogue, improves performance against specific organizational goals, improves employees' understanding of the link between performance and organizational goals and leads to positive behaviour to achieve 
them (Armstrong, 2006; DeCenzo \& Robbins, 2005; Dixon, 2004; Hale, 2004; Kates, Marconi \& Mannle, 2001; Poister, 2003). On the other hand, a PMS that is poorly implemented can have dire consequences in terms of an organization's goals and the effective management of its human resources. The focus of this case study is on the effects of a poorly implemented PMS in the Buffalo City Metropolitan Municipality (BCMM) in South Africa, on the job behaviour and performance of its employees. An assumption of this study is that the PMS is well designed and appropriate for the BCMM.

There is a view that the inappropriate job performance and behaviour such as lack of service delivery, fraud and corruption at the BCMM could be attributed to lack of capacity (Mawonga, 2012; Benya 2011). It suggests that the number of available personnel is insufficient and lack capacity and thus need to be appropriately trained and provided with relevant tools and infrastructure (Mntengwana, 2013; Bengeza, 2013; Gourrah, 2011; Buffalo City Metropolitan Municipality, 2010). Lack of capacity could indeed be the cause of inappropriate job behaviour and performance due to ignorance and misunderstanding of organizational policies. Erroneous discharge of duties by workers is understandable in an environment such as the BCMM where some workers are "overworked due to staff shortages" (Gourrah 2011, p. 3). On the other hand, purposeful inappropriate job behaviour and performance is often committed with some level of understanding of the wrongfulness of the act and with the capacity to prevent or avoid it. That is why it is ironical when workers' job behaviour and performance is inappropriate although they are capacitated, through formal education, to perform well and be productive in their respective occupations. The qualification-occupation link is, however, highly debatable because the issue of matching qualifications with jobs is complex. For instance, occupations like being the country's president involve significant levels of administration and management, but such appointments are generally made on political rather than academic merit as no one goes to school to enrol for a course on becoming a president. The importance of using formal education credentials as the basis for appointment is often diminished by the fact that inappropriate job behaviour and performance has been manifested by those appointed both on political and academic grounds. On the basis of disappointed expectations from formal education, some scholars have concluded that "education is useless" (Cottom, 2003, p. 1). Widespread inappropriate behavior of fraud and corruption by even those with formal education calls into question the impact of education on job behaviour and performance. The BCMM workers' inappropriate job behaviour and performance is a serious setback for functionalist claims about education as even some of those appointed on academic merit do not reflect appropriate ethics, attitudes and values.

The BCMM's ability to cope with its responsibilities has been called into question by reports of poor administration; weak management of finances, human resources and assets; inappropriate job performance and behaviour by some municipal workers and other challenges (Nombembe, 2013; Nombembe, 2011; Coetzer, 2009; Times Live, 2011). Such claims appear regularly in the media and further evidence is available from various sources like audit reports, parliamentary discussions, reports to parliament, and municipal and departmental reports. The cases of inappropriate job behaviour and performance at the BCMM show that it is experiencing financial mismanagement, lack of service delivery, fraud and corruption (Mawonga, 2012; Benya, 2011). There is more evidence which suggests that the BCMM is characterised by maladministration, mismanagement and misappropriation of resources (Mawonga, 2012; Benya, 2011). The Auditor General revealed that the BCMM has never received a clean audit from his office. Since the 2002/03 financial year, it has received many qualified audit opinions, disclaimers and adverse audit reports and regressed further to an adverse opinion in the 2010/11 financial year (Nini, 2012a; 2012b). The adverse audit opinion is worse than a disclaimer as it means the Auditor General believes the municipal financial statements contained false information or that some facts were left out (De Kock, 2012). In fact, the Auditor General rated the BCMM as the worst metropolitan council in the 2010/11 audit (Times Live, 2012). The Auditor General, in his latest report (Mokone \& De Kock, 2014), notes that this reflects a concerning picture on the drivers of the internal control environment, a lack of policies, procedures and controls for document management, the absence of daily and monthly financial controls, as well as poor monitoring of compliance with legislation.

On the basis of negative reports about the BCMM from audits, forensic investigations and the media, it is evident that this municipality needs to implement its PMS effectively. It is for this reason that the BCMM introduced several mechanisms to address the challenge of inappropriate job behaviour and performance which translated to the negative reports. The mechanisms include the appointment of people to curb the misappropriation of resources. Hence, behavioural elements in the PMS include the identification of job behaviours, behaviour 
monitoring, positive behaviour reinforcement, inappropriate behaviour correction, and setting behavioural expectations (Singh \& Twalo, 2014; Twalo, 2014). Rotundo (2002) observes that "researchers agree that job performance can be defined on a micro-level as actions and behaviours of an employee that contribute to the goals of the organisation" (p. 2). However, caveat is in order because, "whilst performance is behaviour not all behaviour is performance - only behaviour that is goal-relevant counts as performance" (Williams, 1998, p. 95). Churchill, Ford, and Walker (1990) agree that performance "is behaviour evaluated in terms of its contributions to the goals of the organisation" (p. 729). Performance thus has a normative element which reflects whether the workers' performance is appropriate or otherwise in relation to the organisation's objectives. In the same vein, the business dictionary (Web Finance, 2013) defines job performance as "work related activities expected of an employee and how well those activities were executed" (p. 1). With respect to behaviour, Churchill, Ford and Walker (1990) observe that it refers to what the workers actually "do - that is, the tasks they expend effort on while working" (p. 729). The business dictionary (Web Finance, 2013) definition of job behaviour seems to be outcome-based: "pattern of actions and interactions of the members of an organisation that directly or indirectly affects [their productivity]" (p. 1).

PM is critical to ensure that organizational plans in the BCMM are being implemented, that they have the desired developmental impact and that resources are being used efficiently to establish and maintain a serviceorientated culture in the organization. As such PM and integrated development planning are two sides of the same coin - the Integrated Development Plan sets out what a municipality intends to achieve, i.e. what the community can expect and the PMS manages, measures and evaluates the extent of achievement thus assisting the community to inspect what it expected (Overstrand Municipality, 2008). Effective PM entails articulation of the organization's vision, establishment of core objectives, and identification of operational objectives (Pun \& White, 2005; Aguinis, 2005; Armstrong, 2006). To inform decision-making, the performance of employees then needs to be regularly measured through indicators which measure the establishment of effective departmental controls, monitoring and continuous control of quality in the organization by four key performance measures of quality, delivery, cycle time and waste (Watts \& McNair-Connolly, 2012; Johnson, 2005). This connotes that the PMS should make explicit the difference between measures that are of interest to external parties - such as customer satisfaction, quality and delivery - and measures that are of interest within the organization such as productivity, cycle time and waste (Johnson, 2005).

Holistic PM is necessitated by the symbiotic relationship between organizational context and workers' performance. In fact, job context is a key determinant of performance as factors such as the availability and quality of equipment, degree of staff support, working conditions, actions of co-workers, management style, remuneration and organizational policies play a key role in workers' performance (Council of UC Staff Assemblies, 2011; Twalo, 2014; Singh \& Twalo, 2014 ). The main objective of a PMS is to ensure job behavior and performance of employees and is linked to the overall objectives of the organization. Therefore, a diagnosis of job performance problems in this case study of the BCMM is important because these challenges involve compromised service quality and this does not augur well for the sustainability of its metropolitan status.

\section{APPROPRIATE PERFORMANCE MANAGEMENT SYSTEMS}

In light of this study, the research question that inevitably arises is: What is an appropriate PMS? An effective PMS must assist employees to discover their own strengths, to recognise their weaknesses, and to develop their knowledge, skills and attitudes in terms of their expectations and abilities. It must empower them to enhance their individual career development through informed decision-making and focused work-integrated learning training. An appropriate PMS enables employers to identify shortcomings in employment practices, procedures and policies and to delegate unambiguous and realistic responsibilities to employees (Overstrand Municipality, 2008). Such a PMS is based on ethical and operational principles that serve to ensure the system is fair, equitable and achieve performance management as well as human resources development. The guidelines that are used to design the system, implement it and reach conclusions and judgements about performance must be objective, balanced and must apply to all employees equally. Individual performance appraisals of all levels of staff are to be treated confidentially. The performance objectives to be achieved by individual employees must be mutually agreed to by the employee to be appraised (the appraisee) and the person responsible for the appraisal (the appraisor). As such, it must be transparent to all employees and the objectives must be reasonable, realistic and measurable. Employees 
must receive continuous feedback on the results of the performance appraisals in a constructive manner. Feedback must provide employees with an objective appraisal of the current situation and will be linked to appropriate steps to improve performance, including training and coaching objectives. Based on such feedback, realistic time frames must be set for regular measurement of performance on the specific steps mutually agreed to by the appraisor and appraisee in the organization (Overstrand Municipalty, 2008). The PMS designed for the BCMM is intended to empower the employees to execute their tasks in terms of their abilities and to attain job satisfaction. When this organizational goal is not achieved, then the perceived problem lies with the implementation, instead of the design of the PMS.

To achieve its economic development mandate, the BCMM needs to apply the various management functions which include performance, financial, human resources, asset, operations and service quality management. This is crucial, especially in light of the suggestion that poor municipal service delivery is due to lack of management skills (Kwinana, 2010; Krapohl, 2007; Twalo, 2014; Singh \& Twalo, 2014). For this reason, Krapohl (2007) emphasises the importance of efficient management practices in municipalities since they have an enormous service delivery challenge which requires them to "display, and embody, the virtues of transparency, accountability, participation and effective use of resources" (p. 15). In Section 153 of the South African Constitution (The Constitution of South Africa, 2011), service delivery is portrayed as the developmental role requiring that "a municipality must structure and manage its administration, budgeting and planning processes to give priority to the basic needs of the community and to promote the social and economic development of the community" (p. 77). The seriousness of the municipal responsibility necessitates efficacious application of management principles, because the growth and development of every economy hinge on how resources are judiciously managed and increased. Having designed or selected an appropriate PMS, too many organizations appear to assume that implementation and maintenance require little or no attention, and then managers begin to question as to why the system has fallen into disuse or disrepute, as may be the case with the BCMM. Research confirms the importance of the following contributory factors towards the preservation of a sustainable PMS (Holloway, 2009; Aguinis, 2005; Armstrong, 2006):

1. Allow sufficient time to listen to as many people and draw on as many information sources as possible. Senior managers can identify core capabilities, knowledge and skills needed by the organization's value and supply chains, while employees can shape the development of relevant measures and identify suitable alternative routes to change.

2. Be process-led at all stages. As well as mapping and managing the performance of processes per se, approaches such as benchmarking and the Balanced Scorecard incorporate powerful processes for sharing understanding about what each division or department of the organization does, improving communications and highlighting knock-on effects of changes.

3. Keep an open mind about what measures to incorporate, and change them if they don't meet the needs of enough stakeholders. Be proactive and sensitive to different organizational sub-cultures.

4. In complex organizational settings, don't expect many direct relationships between causes and effects. For example, the evidence suggests that when payment systems are used as interventions and catalysts for broader organizational changes, they have led to some improvements in motivation and satisfaction. But simply linking 'pay' to 'performance' may not have the desired effect.

5. Effective PM requires effective management, a key component of which is building relationships across organizational boundaries, and appreciating the impact of PMSs on sub-systems such as training and development, appraisal and information systems.

The attribution of inappropriate job behaviour and performance to lack of work-integrated learning skills of its employees (Kaseke, 2011; Stokes, 2010) by one school of thought, and to poor work ethic of employees (Faling, 2011) by another school of thought demonstrates the need for a multipronged approach to such an investigation. Kaseke (2011) argues that a lack of skills hampers effective service delivery and it also leads to mismanagement of resources in most instances. Conversely, Faling (2011) argues that "the 'skills shortage' has become a convenient scapegoat for most shortcomings in service delivery by municipalities, public utilities and government departments. Businesses in the private sector often use the same lament as an excuse for sloppy service" (p. 1). He further argues that many service delivery grievances require the most basic skills as one does not "need a BSc Chem Eng degree to detect sewerage running into the streets" or "a CA qualification... to sort out an R12 000 municipal account 
presented to a pensioner living in a cluster home" (Ibid.). For this reason, he attributes the lack of service delivery to a pervasive poor work ethic and argues that without discounting legitimate skills problems, the country (South Africa) is suffering from a work ethic problem.

The compromised service delivery, corruption, maladministration, and poor financial management, corroborated by the several qualified audit reports the BCMM has received, media reports, and other sources of government communication, underscore the loopholes in the BCMM's management and control systems. Weak management also contributes to poor service delivery and delay in many development projects, as funding for this purpose gets misused through theft, corruption, fraud, overspending, under-spending and wasteful expenditure. A case in point is the BCMM's withdrawal of funding for development projects in an effort to curb mismanagement and corruption after the Ernst and Young forensic report revealed mismanagement of about R2 billion (New Age, 2011). The use of PMSs in many organizations (such as the BCMM) suffer from flaws that can undermine these organizations' ability to make better decisions, and these fatal flaws can be summed up as follows (Castellano, Young \& Roehm, 2004, pp. 32-35):

1. Ignoring the performance contributions of interactive system elements. The first fatal flaw can possibly stem from the failure of viewing an organization as a system. All organizations are systems: networks of interdependent processes that work together to accomplish the organizations' objectives. The goal for the BCMM should therefore be to optimize the overall system and this can be achieved by recognizing the interrelationship between the various components within the system and the need to remove all barriers to system optimization.

2. Misunderstanding variation. The second fatal flaw, and perhaps the root of all of the other problems associated with traditional PMSs, is a failure to address variation. It is important to understand in the BCMM what happens when any process measurement fails to take variation into consideration. There will always be inherent variation in every system component: manpower, machines, methods, materials, and environment. Yet advocates of stretch targets and benchmarking ignore variation both in setting targets and analyzing results. Unfortunately, traditional methods to establish targets or measure results cannot determine process capability. Also important is the inherent inability of a stable process to achieve some point-specific target each and every reporting period because variation in any process is inevitable as is evident in the BCMM.

3. Confusing signals with noise. This flaw, which also relates to variation, is the inability of traditional measurement systems to distinguish between signals and noise when analyzing process results. Noise occurs when the variation is random and signals nothing. The ability of process behaviour charts to give management a methodology to distinguish between signals and noise provides a statistically-based method of analysis superior to traditional analysis. Systems that focus on single-point methods of analysis treat every unfavourable result as a negative signal. Untold amounts of time, money, and talent can be unwittingly wasted as process managers attempt to explain negative results, when only random variation may be present.

4. Misunderstanding psychology. The financial reporting disasters of many organizations such as Enron and Sunbeam provide ample evidence of what can happen when the figures are distorted to get better results. Yet in the midst of these devastating failures, very little attention has been paid to the enormous pressure that can occur when an organization's PMS is used to align and motivate employee behaviour. What is questionable is the continued usage of stretch targets and benchmarking as such targets can lead to distortion of the system and the figures, as fearful workers would try to achieve the numerical goal even though this was beyond their capabilities.

5. Confusing the voice of the customer with the voice of the process. When management sets targets, these metrics represent what management, in this case the internal customer, wants the specifications or results to be. This target-setting process, usually in the context of some management by objective or management by result initiative, is predicated on management's determination to align employee behaviour and motivation to achieve any predetermined result or best practice. While it is true that meeting such specifications is necessary, management's specification - the voice of the customer-does not ensure that the underlying process generating the results - the voice of the process - is capable of achieving these results. Unless process behaviour charts and capability analysis are used, management cannot determine whether the stretch or benchmarked targets are within the capability of the existing process. 
6. Failure to support a process view. The growing popularity of the balanced scorecard (BSC) approach attests to the desire of organizations to link their strategies to performance measurement systems that identify the leading and lagging indicators of their metrics across four key perspectives: learning and growth, internal business process, customer, and financial. To achieve these linkages, companies adopting BSC initiatives must be cognizant of the importance of key processes that are vital to achieving their strategy. The failure to support a process view of a company with a process measurement focus seriously jeopardizes an entity's ability to evaluate and manage key processes. Whether for BSC or some other process management focus, the failure to set improvement targets or to analyze process results with the use of process behaviour charts opens the company to all of the fatal flaws previously discussed. Process goals and targets (the voice of the customer) cannot realistically be established if the voice of the process is ignored. Traditional methods of target-setting and analysis have no way of informing management whether a variation in results is either signal or noise, or even whether the established target is within the capability of the process. Lack of such information seriously undermines an organization's efforts to manage from a process focus.

7. Misunderstanding the real role of measurements. The final fatal flaw is a failure to understand the real role of performance measurements. The prevailing view of performance measurement is that its role is to measure outcomes or results against a predetermined set of targets, with the usual approach involving the following steps:

- $\quad$ Set numerical targets - usually stretch or benchmarked metrics.

- $\quad$ Use these targets to align and motivate employee behaviour.

- $\quad$ Analyze results within set time periods.

- $\quad$ Evaluate employees on the basis of the results achieved.

- Reward or sanction accordingly.

This process is deceptively simple and fatally flawed for all of the reasons previously discussed. What should be the proper role of measurements? Measurement systems should focus on providing management with the feedback they need to monitor or improve key processes since commendable results can only come from good processes. Numerical targets, even those that utilize stretch goals or benchmarks, can be beneficial, provided that these targets are used in the context of capability analysis and process behaviour charts. By using them, management can gain valuable insights about process performance which is the key to achieving better results. This information would not only allow management to distinguish between signals and noise, but would also provide vital information necessary for process improvement initiatives and more-informed decision making. Stretch targets and benchmarked metrics, coupled with traditional methods of analysis, do not provide management with meaningful feedback about process performance. Such methods of measurement and analysis waste valuable time, talent, and resources that could be better utilized in improving the organization's key processes in order to achieve better results.

Management must gather and analyse data that will empower employees become better contributors to the organization's objectives and vision. In many organizations just the reverse happens: Measures define what is meaningful instead of letting the work itself define the measures. As employees increasingly focus on the measurements, they disconnect from the larger purpose of the organization and do only what is required and measured. The results that inevitably follow are therefore fatally flawed (Castellano, Young \& Roehm, 2004).

\section{RESEARCH DESIGN}

This paper is based on a study that used the mixed method approach, that is, a combination of qualitative and quantitative methods (Creswell \& Plano-Clark, 2007). The quantitative method was in the form of a questionnaire with 79 closed-ended questions, which included 10 biographical questions. The questionnaire had 6 qualitative questions, thus the total number of questions was 85. Purposeful sampling was used since special attention had to be also paid to staff with formal education in order to investigate the co-existence of formal education with inappropriate job behaviour and performance. However, many workers (49\%) had no matric and most of them were in elementary occupations (Buffalo City Metropolitan Municipality, 2011). The level of formal education was therefore not made a prerequisite because most workers' education level was commensurate with 
their occupations. Taking these technicalities into consideration, the research questions then sought to probe how inappropriate job behaviour and performance persisted in the respective occupations despite the commensurate education credentials.

This paper therefore focuses only on three sub-sections of the questionnaire:

- $\quad$ BCMM workers' capacity in terms of their qualifications to do the work;

- $\quad$ BCMM workers' job performance in providing quality service to their customers;

- $\quad$ BCMM workers' job environment with the focus being on the availability of materials to do the job, and whether continuous support is provided by supervisors and managers to their employees.

$\mathrm{BCMM}$ workers were requested to complete and return the questionnaire that was sent to them by email and fax, and later hand delivered. As of 30 June 2012, the BCMM had 8 directorates, 39 departments and a total staff complement of 5427 (Buffalo City Metropolitan Municipality, 2012). Ten respondents per department were meant to be sampled for responding to the questionnaire, so as to have 390 respondents in total. For the structured interviews, one person was expected to be sampled per directorate, so as to have eight interviewees in total. However, due to fieldwork logistics that included high rate of refusal to participate in some departments, the share of respondents per department could not be balanced. Consequently, some departments were over-represented and others were under-represented. In lieu of getting 398 respondents ( $7 \%$ of the total staff complement), only 342 (6\% of the total staff complement) could participate. However, physically administering the questionnaire around the BCMM offices meant that the respondents were much more than 342 . This is because the researcher had to explain to the workers, including those who refused to complete the questionnaire, what the questionnaire was about. In return, those who agreed to participate in this research spoke about their experiences and observations at the BCMM. The refusal by some employees to complete the questionnaire was on account of lack of time, fear of victimisation because the environment was highly political, and research fatigue by those who felt that they had participated in too many research projects, yet nothing seemed to change. Participation in this study was voluntary and all participants were made aware of this through the covering letter. Their confidentiality was also promised with the covering letter undertaking that participants' personal details would not be disclosed under any circumstances. There would therefore be no risk of harm, embarrassment or offence to any participant or to the municipality. In fact, the biographical information section enabled them to remain anonymous since the required information was about their directorates and departments, type of employment, tenure, and educational qualifications. The covering letter also noted that there were no risks or discomforts associated with participation.

\section{RESULTS}

For the quantitative data analysis, empirical statistical data were captured and processed by a qualified statistician. For measuring the internal consistency (reliability) of the instrument, Cronbach's alpha was used. The levels of reliability appeared to be high with an average of 0.75 for employees' job behaviour and an average of 0.82 for employees' job performance. Descriptive statistics are used to analyse the findings pertaining to the three focus areas of this paper. Descriptive statistics describe the main features of the quantitative data and are used to present quantitative descriptions in a manageable form, seeing that it enables researchers to facilitate large data in a way that easily makes sense (Malim \& Halim, 2011). For the purpose of analysis of each item, the percentages of the two columns indicating disagree strongly and disagree are combined. The same procedures applied to the two columns indicating agree and strongly agree. Hence, frequent reference is made in the analysis as to whether the respondents disagreed (combining strongly disagree responses with disagree responses) or agreed (combining strongly agree responses with agree responses) respectively. 


\section{Key for Table}
DS: Disagree Strongly
A: Agree
D: Disagree
M: Mean
AS: Agree Strongly
$\mathbf{N}$ : Neither Agree nor Disagree
VR: Valid Responses

\section{BCMM Workers' Capacity}

Table 1 provides the descriptive statistics on the BCMM workers' capacity to do their work, and the mean and standard deviation for each item is also shown.

Table 1: BCMM Workers' Capacity

\begin{tabular}{|c|c|c|c|c|c|c|c|c|c|}
\hline & & DS & D & $\mathbf{N}$ & A & $\mathbf{A S}$ & VR & $\mathbf{M}$ & SD \\
\hline B1.1 & $\begin{array}{l}\text { BCMM capacity development } \\
\text { programmes improve workers' job } \\
\text { performance }\end{array}$ & 8.16 & 27.20 & 53.47 & 6.34 & 4.83 & 331 & 2.73 & 0.88 \\
\hline B1.2 & $\begin{array}{l}\text { People who studied in previously } \\
\text { White institutions stand a better chance } \\
\text { of finding employment in the BCMM }\end{array}$ & 8.26 & 28.44 & 32.11 & 27.83 & 3.36 & 327 & 2.90 & 1.01 \\
\hline B1.3 & $\begin{array}{l}\text { People with the right educational } \\
\text { qualifications, but wrong ethical } \\
\text { conduct are employed in the BCMM }\end{array}$ & 4.35 & 27.64 & 12.11 & 51.24 & 4.66 & 322 & 3.24 & 1.05 \\
\hline B1.4 & $\begin{array}{l}\text { My qualifications are relevant to the } \\
\text { kind of work I do on a daily basis }\end{array}$ & 2.15 & 27.30 & 2.45 & 57.67 & 10.43 & 326 & 3.47 & 1.07 \\
\hline B1.5 & $\begin{array}{l}\text { What is important when working are } \\
\text { the results and not how the job is done }\end{array}$ & 6.76 & 32.31 & 28.31 & 27.08 & 5.54 & 325 & 2.92 & 1.04 \\
\hline
\end{tabular}

Only $11.17 \%$ of respondents were in agreement that the BCMM development programmes improved workers' job performance. A large percentage (53.47\%) preferred to remain neutral while $35.36 \%$ of respondents disagreed. On the issue of being at an advantage by getting a qualification from a historically white educational institution, $32.11 \%$ of the respondents were noncommittal. In contrast, $31.19 \%$ agreed, whereas $36.7 \%$ felt that there was no such advantage to find employment in the BCMM. The majority of respondents (55.9\%) felt that people with the right qualifications, but wrong ethical conduct are employed in the BCMM. In contrast, $31.99 \%$ disagreed while $12.11 \%$ neither agreed nor disagreed. Most of the respondents $(68.1 \%)$ believe that their qualifications are relevant to the kind of work they do on a daily basis, whereas $29.15 \%$ disagreed, with a small margin of $2.45 \%$ of the respondents being neutral on this issue. On the question of whether the results or outcomes of their job inputs are important when working, and not how the job is done, $32.62 \%$ of the respondents agreed while $39.07 \%$ disagreed, with $28.31 \%$ of the respondents being uncertain.

\section{BCMM Workers' Job Performance}

The respondents' responses that relate to job performance are given in Table 2 and the mean and standard deviation for each item is also shown. 
Table 2: BCMM Workers' Job Performance

\begin{tabular}{|c|l|c|c|c|c|c|c|c|c|}
\hline & \multicolumn{1}{|c|}{$\mathbf{D S}$} & $\mathbf{D}$ & $\mathbf{N}$ & $\mathbf{A}$ & $\mathbf{\text { VR }}$ & $\mathbf{M}$ & SD \\
\hline D1.1 & $\begin{array}{l}\text { Workers are uncertain about how to } \\
\text { perform their respective tasks }\end{array}$ & 6.12 & 33.23 & 29.68 & 29.35 & 1.61 & 310 & 2.87 & 0.96 \\
\hline D1.2 & $\begin{array}{l}\text { People are held accountable for the } \\
\text { quality of work they produce }\end{array}$ & 4.55 & 30.52 & 50.97 & 8.12 & 5.84 & 308 & 2.80 & 0.87 \\
\hline D1.3 & $\begin{array}{l}\text { Workers are prepared to go an extra } \\
\text { mile to ensure that their jobs are done } \\
\text { well }\end{array}$ & 27.74 & 5.48 & 29.35 & 32.91 & 4.52 & 310 & 2.81 & 1.28 \\
\hline D1.4 & $\begin{array}{l}\text { My department responds to crises as } \\
\text { they arise, rather than planning } \\
\text { appropriately in advance }\end{array}$ & 5.18 & 27.51 & 31.39 & 29.77 & 6.15 & 309 & 3.04 & 1.01 \\
\hline D1.5 & $\begin{array}{l}\text { BCMM internal procedures negatively } \\
\text { affect my job performance }\end{array}$ & 3.59 & 52.29 & 7.51 & 32.03 & 4.58 & 306 & 2.82 & 1.07 \\
\hline D1.6 & $\begin{array}{l}\text { The quality of service from staff } \\
\text { discourages customers from dealing } \\
\text { with the BCMM again }\end{array}$ & 4.87 & 26.62 & 31.49 & 31.83 & 5.19 & 308 & 3.06 & 0.99 \\
\hline D1.7 & $\begin{array}{l}\text { There are too many workers in relation } \\
\text { to the responsibilities of my } \\
\text { department }\end{array}$ & 37.98 & 28.90 & 7.47 & 24.35 & 1.30 & 308 & 2.22 & 1.23 \\
\hline D1.8 & $\begin{array}{l}\text { The workers like their jobs } \\
\text { Danagers struggle to exercise control } \\
\text { in my department }\end{array}$ & 4.87 & 28.25 & 51.95 & 9.09 & 5.84 & 308 & 2.83 & 0.88 \\
\hline D1.10 & $\begin{array}{l}\text { Workers are mindful of the impact of } \\
\text { their actions on others such as } \\
\text { colleagues, clients and service } \\
\text { providers }\end{array}$ & 3.56 & 5.50 & 53.08 & 32.36 & 5.50 & 309 & 3.31 \\
\hline
\end{tabular}

More respondents (39.35\%) disagreed that they are uncertain about how to perform their respective tasks, as compared to only $30.96 \%$ of respondents who agreed, and $29.68 \%$ were uncertain. Most respondents (50.97\%) preferred to remain neutral on the issue of workers being held accountable for the quality of work they produce. Only $13.96 \%$ agreed, whereas $35.07 \%$ of the respondents disagreed. Only $37.43 \%$ of respondents observed that workers are prepared to go an extra mile to ensure that their jobs are done well. In fact, $33.22 \%$ of respondents observed that workers are not prepared to go an extra mile while $29.35 \%$ had no opinion in this regard. Many respondents $(35.92 \%)$ felt that their departments only respond to crises as they arise, rather than planning appropriately in advance. A large number (31.39\%) were uncertain, whereas $32.69 \%$ disagreed. A significant number $(55.88 \%)$ of respondents disagreed that the internal procedures at the BCMM negatively affect their job performance. A very small percentage $(7.51 \%)$ remained neutral on this issue, whereas $36.61 \%$ agreed. Many respondents $(37.02 \%)$ felt that the quality of service from staff discourages customers from dealing with the BCMM while $31.49 \%$ disagreed. A large percentage $(31.49 \%)$ were uncertain. A significant number of respondents $(66.88 \%)$ disagreed that there are too any workers in relation to the responsibilities of their departments. Only $25.65 \%$ agreed while $7.47 \%$ remained noncommittal. Only $37.46 \%$ of the respondents agreed that they liked their jobs while $32.25 \%$ did not know whether they liked their jobs or not. Many workers (30.29\%) indicated that they did not like their jobs. Most of the respondents (51.95\%) were uncertain whether their managers struggle to exercise control in their department. On the other hand, a small number (14.93\%) agreed that their managers struggle to exercise control whereas $33.12 \%$ disagreed. Most of the respondents $(53.08 \%)$ were also uncertain whether the workers are mindful of the impact of their actions on others such as colleagues, clients and service providers. A few $(9.06 \%)$ disagreed while $37.86 \%$ of the respondents agreed.

\section{BCMM Workers' Job Environment}

The respondents' responses that relate to their job environment are given in Table 3, and the mean and standard deviation for each item is also shown. 
Table 3: BCMM Workers' Job Environment

\begin{tabular}{|c|c|c|c|c|c|c|c|c|c|}
\hline & & DS & D & $\mathbf{N}$ & A & AS & VR & $\mathbf{M}$ & SD \\
\hline E1.1 & $\begin{array}{l}\text { There is enough material for all the } \\
\text { workers to use in doing their jobs }\end{array}$ & 36.72 & 32.13 & 2.30 & 27.54 & 1.31 & 305 & 2.25 & 1.25 \\
\hline E1.2 & $\begin{array}{l}\text { The BCMM provides enough } \\
\text { protection for people who disclose } \\
\text { corruption }\end{array}$ & 9.54 & 28.95 & 59.21 & 1.32 & 0.98 & 304 & 2.55 & 0.72 \\
\hline E1.3 & $\begin{array}{l}\text { There is daily monitoring of } \\
\text { workers' activities to ensure that } \\
\text { tasks are done properly }\end{array}$ & 32.13 & 30.17 & 28.85 & 5.57 & 3.28 & 305 & 2.18 & 1.05 \\
\hline E1.4 & $\begin{array}{l}\text { There is weekly and/or monthly } \\
\text { evaluation and feedback of } \\
\text { workers' job performance }\end{array}$ & 35.21 & 30.26 & 4.93 & 27.96 & 1.64 & 304 & 2.31 & 1.26 \\
\hline E1.5 & $\begin{array}{l}\text { My job has more attractive than } \\
\text { unattractive characteristics }\end{array}$ & 4.63 & 26.73 & 32.67 & 32.34 & 3.63 & 303 & 3.04 & 0.96 \\
\hline E1.6 & $\begin{array}{l}\text { People sometimes blame me for } \\
\text { problems over which I have no } \\
\text { control }\end{array}$ & 3.92 & 1.96 & 54.91 & 32.35 & 6.86 & 306 & 3.36 & 0.80 \\
\hline E1.7 & $\begin{array}{l}\text { Management's understanding of } \\
\text { how workers should do their jobs is } \\
\text { different to how the workers } \\
\text { understand the jobs should be done }\end{array}$ & 2.96 & 26.32 & 32.24 & 33.55 & 4.93 & 304 & 3.11 & 0.95 \\
\hline E1.8 & My manager manages conflict well & 6.27 & 28.05 & 29.71 & 32.34 & 3.63 & 303 & 2.99 & 1.00 \\
\hline E1.9 & $\begin{array}{l}\text { Many people get employed in the } \\
\text { BCMM because of who they know, } \\
\text { rather than what they know }\end{array}$ & 3.61 & 26.55 & 5.90 & 29.84 & 34.10 & 305 & 3.64 & 1.29 \\
\hline E1.10 & $\begin{array}{l}\text { The BCMM has an effective policy } \\
\text { to get rid of unproductive workers }\end{array}$ & 33.88 & 4.61 & 33.22 & 25.33 & 2.96 & 304 & 2.59 & 1.27 \\
\hline E1.11 & $\begin{array}{l}\text { The BCMM views mismanagement } \\
\text { of assets like money, vehicles and } \\
\text { telephones as a serious offence }\end{array}$ & 3.31 & 27.72 & 31.02 & 32.67 & 5.28 & 303 & 3.09 & 0.97 \\
\hline E1.12 & $\begin{array}{l}\text { There is regular communication } \\
\text { between workers and management } \\
\text { about work-related issues }\end{array}$ & 9.12 & 29.97 & 28.99 & 29.97 & 1.95 & 307 & 2.86 & 1.01 \\
\hline E1.13 & $\begin{array}{l}\text { When my colleagues do their jobs } \\
\text { badly, they do not mind if others } \\
\text { suffer as a result }\end{array}$ & 5.86 & 29.65 & 30.29 & 28.99 & 5.21 & 307 & 2.98 & 1.02 \\
\hline E1.14 & $\begin{array}{l}\text { People who have friends in some of } \\
\text { the BCMM departments find it } \\
\text { easy to get their administrative } \\
\text { requirements attended to rapidly }\end{array}$ & 2.29 & 25.49 & 4.90 & 33.99 & 33.33 & 306 & 3.71 & 1.24 \\
\hline
\end{tabular}

Most of the respondents disagreed (68.85\%) that there is enough material for all the workers to use in doing their jobs, while $28.85 \%$ agreed and a few preferred to remain neutral on this issue. Surprisingly, possibly for fear of victimization, $59.21 \%$ of the respondents preferred to remain neutral on the issue of whether the BCMM provides enough protection for people who disclose corruption. Only a small number of respondents $(2.3 \%)$ agreed while $38.49 \%$ disagreed, confirming that minimal or no protection was afforded to employees who disclosed corruption. Only $8.85 \%$ of the respondents agreed that there is daily monitoring of their jobs to ensure it's done properly. In contrast, most of the respondents $(62.3 \%)$ disagreed while $28.85 \%$ were uncertain about the monitoring of their tasks. In addition, $65.47 \%$ also disagreed that there is weekly or monthly assessment of their work. Only $4.93 \%$ preferred to remain neutral on this issue while $29.6 \%$ agreed. Whether their jobs have more attractive rather than unattractive characteristics, $35.97 \%$ agreed, $31.36 \%$ disagreed while the rest preferred to be neutral. A small percentage of workers believe that they are sometimes blamed for problems over which they have no control. Surprisingly, a large percentage $(54.91 \%)$ preferred to remain noncommittal probably not to create a conflict with their line managers, while $39.21 \%$ of the respondents agreed that they were blamed for such problems. 
More respondents (38.48\%) agreed than disagreed (29.28\%) on the understanding between management and the workers of how the work should be done. Regarding whether their managers handled conflict well, the responses between those who agreed (35.97\%) and disagreed $(34.32 \%)$ did not differ much while $29.7 \%$ were uncertain of their managers' ability to handle conflict. Significantly, $63.94 \%$ of the respondents strongly felt that employment opportunities at the BCMM was based more on who the employees knew rather than what they knew in terms of the knowledge and skills of their jobs. Only 5.9\% were uncertain while $30.16 \%$ disagreed because they felt that it was not who they knew, but what they know about the jobs that enabled them to get employed. Although $38.49 \%$ of respondents observed that the BCMM's policy of getting rid of unproductive workers is ineffective, $28.29 \%$ think it is effective and 33\% were neutral. The responses on whether the BCMM views mismanagement of assets as a serious offence were almost similar with $37.95 \%$ who agreed while $31.03 \%$ disagreed and $31.02 \%$ preferred to be noncommittal. Many respondents disagreed (39.09\%), as compared to those who agreed (31.92\%), that there is regular communication between workers and management about work-related issues. Only $34.2 \%$ of the respondents agreed that when their colleagues did their jobs badly, they did not mind if others suffered the consequences. Almost a similar number disagreed (35.51\%) while $30.29 \%$ preferred to remain noncommittal. A significant number of respondents agreed $(67.32 \%)$ that people who have friends in some of the BCMM departments found it easier to get their administrative requirements attended to rapidly. Only $4.9 \%$ of the respondents were neutral while $27.78 \%$ disagreed.

\section{DISCUSSION}

In the implementation of a PMS, one of the imperatives is that managers ensure that their employees' outputs are compatible with that of their organizations' goals. In a poorly implemented PMS as is evident in the findings of this case study, only $8.85 \%$ of the respondents agreed that there is daily monitoring of their jobs to ensure it's done properly. The fact that monitoring and evaluation systems seem to be weak could be a fertile ground for proliferation of an unproductive workforce. That $62.3 \%$ of respondents who observed that there is no daily monitoring of workers' activities to ensure that tasks are done properly shows that the environment is conducive to mediocrity. In addition to the mechanisms for monitoring job behaviour and performance already implemented at the BCMM, much still needs to be done because the problem seems intractable. However, in light of the corrective and punitive measures taken against some workers, and the 52\% of noncommittal responses to the question on whether managers struggle to exercise control in their respective departments, it is difficult to ascertain the levels of management control. Therefore, the following factors were identified in this study, suggesting strongly why the PMS at the BCMM is being poorly implemented:

\section{Poor Management Skills}

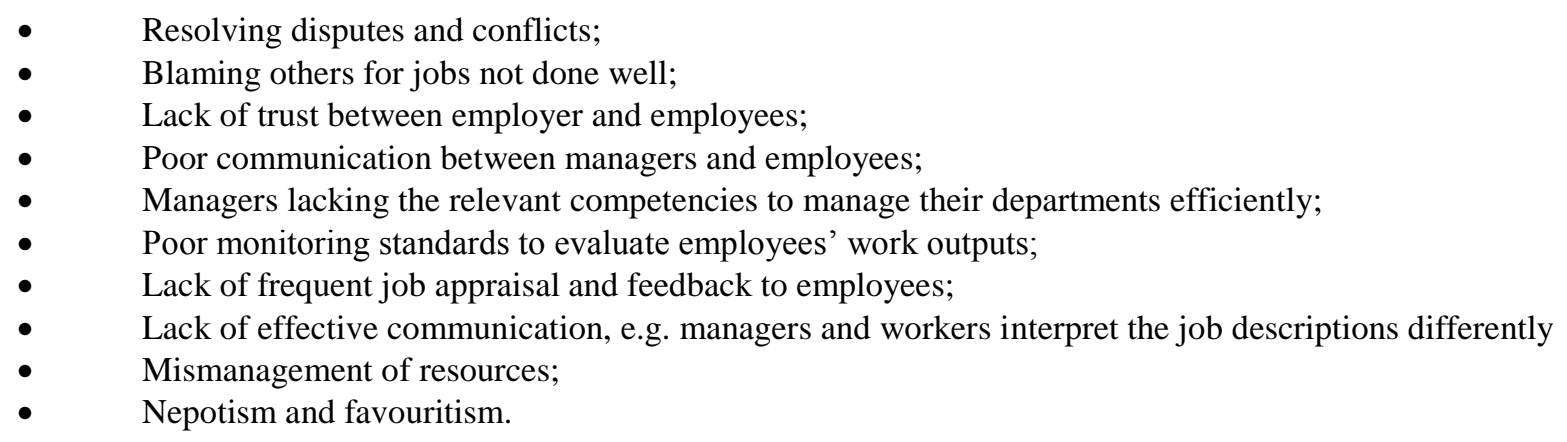


Work-Integrated Learning Skills

- $\quad$ Lack of capacity development programmes to develop the work-integrated learning skills and knowledge of workers as well as their supervisors;

- Workers not knowing exactly what is expected of them in their jobs;

- Appointments not being made on the basis of whether the employee's knowledge is of an appropriate standard.

- Insufficient resources to get the job done effectively;

- $\quad$ Poor employee-job ratios: insufficient number of employees employed to do a specific job, thus burdening the workers with more tasks than what they could manage with;

- Weak management structures that impact negatively on employer-employee relationships;

- $\quad$ Managers lacking the necessary cognitive skills to manage their employees;

- $\quad$ Low levels of emotional intelligence demonstrated by managers.

\section{Addressing Unethical Practices}

- $\quad$ Lack of protection for employees who disclose unethical practices;

- $\quad$ Retaining unproductive workers;

- $\quad$ Ignoring unethical work-related practices;

- Questionable organizational culture and climate that lowers the achievement motivation levels of workers.

The job behaviour and performance of the employees, as is in this case study, is inextricably bound with the PMS which needs to be an organizational policy that clearly spells out the job plans and expectations for all its employees in the implementation, evaluation, and then feedback to remedy gaps in performance. Evidently, a collegial approach is required in the organization such as the BCMM, to successfully implement a PMS. Collegiality is normally embedded in joint decision-making that respects the expertise of all employees as leaders in their fields of specialization. Being bureaucratic can only result in fostering tobephobic leadership practices to the detriment of the organizations' goals, objectives, and vision.

\section{RECOMMENDATIONS}

The findings of this study strongly suggest that the PMS is being poorly implemented in the BCMM. Urgent steps need to be taken to mend this dysfunctional PMS. The US Department of Commerce (2014) explicitly explains that the PM process "is used to communicate organizational goals and objectives, reinforce individual accountability for meeting those goals, and track and evaluate individual and organizational performance results. It reflects a partnership in which managers share responsibility for developing their employees in such a way that enables employees to make contributions to the organization. It is a clearly defined process for managing people that will result in success for both the individual and the organization" (p. 1). In order for the PMS to be successful in the BCMM, the following significant measures need to be incorporated into the PMS (Aguinis, 2005):

- $\quad$ Strategic congruence. The system must be congruent with the unit's and the organization's strategy. Individual goals must be aligned with unit and organizational goals.

- $\quad$ Thoroughness. The system must be thorough regarding four dimensions.

$>\quad$ All employees must be evaluated, including their managers, as a continuous process of identifying, measuring and developing performance in the organization by linking each employee's performance and objectives to the organization's overall mission and goals.

$>\quad$ All major job responsibilities must be evaluated, including behaviours and results.

$>\quad$ The evaluation must include performance spanning the entire review period, and not just the few weeks or months before the review.

$>\quad$ Feedback must be given on positive performance aspects as well as those in need of improvement.

- $\quad$ Meaningfulness. The system must be meaningful in several ways.

$>\quad$ The standards and evaluations conducted for each job function must be considered important and relevant by employees and their employers. 
$>\quad$ Performance assessment must emphasise those functions under the control of the employee.

$>\quad$ Performance appraisal must take place at regular intervals. Simply having one formal evaluation per year is insufficient.

$>\quad$ The system must also provide for continuing work-integrated learning development of evaluators.

$>\quad$ Finally, the results must be used for important personnel decisions. Employees will not pay attention to a system that has no consequences in terms of outcomes they value.

- $\quad$ Specificity. A good system should be specific, meaning that it should provide detailed and concrete guidance to employees about what is expected of them and how they can meet these expectations.

- Identification of effective and ineffective performance. The PMS must provide information allowing for the identification of effective and ineffective performance. That is, the system must allow for distinguishing between effective and ineffective behaviours and results, thereby also allowing for the identification of employees displaying various levels of performance effectiveness. In terms of decision-making, there is no use having a system that classifies or ranks all levels of performance, and all employees, similarly.

- $\quad$ Reliability. A good PMS must include measures of performance that are consistent and free of error.

- $\quad$ Validity. The measures of performance must also be valid. In this context, validity refers to the fact that the measures include all relevant performance facets and do not include irrelevant performance facets. In other words, measures are relevant (i.e., include all critical performance facets), are not deficient (i.e., do not leave any important aspects out), and are not contaminated (i.e., do not include factors outside the control of the employee).

- $\quad$ Acceptability and fairness. A good system is acceptable to and perceived as fair by all participants in the organization. Perceptions of fairness are subjective, and the only way to know whether a system is seen as fair is to ask the participants. We can ask about distributive justice, which includes perceptions of the performance evaluation received relative to the work performed and perceptions of the rewards received relative to the evaluation received. If a discrepancy is perceived between work and evaluation, or between evaluation and rewards, then the system is likely to be seen as unfair. In addition, we can ask about procedural justice, which includes perceptions both of the procedures used to determine the ratings and of the procedures used to link ratings with rewards. Because a good system is inherently discriminatory, some employees will receive ratings lower than those received by other employees. However, we should strive to develop systems seen as fair from both a distributive and procedural perspective. This is because each type of justice perception leads to different outcomes.

- Inclusiveness. Good systems include input from multiple sources on an ongoing basis. First, the evaluation process must represent the concerns of all the people who will be affected by the outcome. Consequently, employees must participate in the process of creating the system by providing input regarding what behaviours and/or results will be measured, and how these job behaviours and performance will be appraised. Second, employee input about their performance should be gathered from the employees themselves before the appraisal meeting.

- $\quad$ Openness. A good PMS has no secrets.

$>\quad$ Job behavior and performance must be evaluated frequently, and performance feedback must be provided on an ongoing basis so that employees are continually informed of their performance.

$>\quad$ The appraisal meeting must consist of a two-way communication process where information is exchanged and not just delivered from the supervisor to the employee.

$>\quad$ Standards must be clear and communicated on an ongoing basis.

$>\quad$ Communications, whether oral or written, must be factual, open and honest.

- $\quad$ Correctability. The process of assigning ratings should minimise subjective aspects. However, it is virtually impossible to create a completely objective system because human judgment is an important component of the evaluation process. So, when employees perceive an error has been made, there should be a mechanism through which this can be corrected. Establishing an appeals process through which employees can challenge what may be unjust decisions is an important aspect of a good performance management system.

- $\quad$ Standardization. As noted above, good systems are standardised. This means that performance is evaluated consistently across people and time. To achieve this goal, the ongoing training of the individuals in charge of appraisals, usually managers, is of paramount importance.

- $\quad$ Ethicality. Good systems comply with ethical standards. This implies that supervisors would suppress their personal self-interest in providing evaluations. In addition, the supervisors would evaluate only 
performance dimensions for which they have sufficient information, while respecting the privacy of their employees.

\section{CONCLUSION}

The findings of this case study strongly suggest that a PMS can be the key factor determining whether an organization can manage its human resources effectively. The PMS provides vital information on whether the workintegrated learning skills of employees are compatible or incompatible with the objectives of their organizations. Evidently, a PMS is critical to assess the success of any organization's human resources. A poorly implemented PMS will therefore fail to motivate an organization's employees, and inevitably their lack of job satisfaction will impact negatively on their self-esteem. This case study reveals that when employees' expectations are not met, inappropriate job behavior and performance can derail the attainment of an organization's goals. It's of paramount importance that employees have the required training to do their work effectively. Therefore, continuous workintegrated learning of all employees is necessary to stay abreast of changes in the work environment. When implemented well, a good PMS would provide critical information that would allow an organization to make sound decisions regarding their people resources. Hence, there should be no room to compromise the use of a welldeveloped PMS to achieve the strategic plans of any organization. Undoubtedly, a good PMS can be a powerful tool to drive organizational effectiveness and change.

\section{AUTHOR INFORMATION}

Prakash Singh is a professor at the Nelson Mandela Metropolitan University in Port Elizabeth, South Africa. He is an NRF rated researcher and a Fulbright scholar. His niche research areas of publication are Organizational Behaviour And Social Psychology. Professor Singh is the author of Innovative Strategies to Develop Better Schools and co-author of Principal Leadership. He has also published widely in peer-reviewed journals and has presented numerous papers at international conferences.

E-mail: Prakash.Singh@nmmu.ac.za

Thembinkosi Twalo is currently employed as a Chief Researcher at the Human Sciences Research Council. His highest qualification is a $\mathrm{PhD}$ degree which he obtained from the Nelson Mandela Metropolitan University in Port Elizabeth, South Africa. His research focus is on job behaviour and performance. He has published several articles in peer reviewed journals and has presented several papers at international conferences.

Email: ttwalo@hsrc.ac.za

\section{REFERENCES}

1. $\quad$ Aguinis, H. (2005). Performance management. Edinburgh: Heriot-Watt University.

2. Armstrong, M. (2006). Performance management: Key strategies and practical guidelines. London: Kogan Page.

3. Benya, Z. (2011). The effectiveness of poverty alleviation initiatives in the Buffalo City Metropolitan Municipality. Unpublished MA dissertation. Port Elizabeth, South Africa: Nelson Mandela Metropolitan University.

4. Bengeza, X. (2013). Mayoral Bursary Fund contributes in alleviating skills Shortage. BCMM Monthly, February: 1-16.

5. Buffalo City Metropolitan Municipality. (2010). Buffalo City Metropolitan Annual Report 2009/2010. Retrieved from: http://www.buffalocity.gov.za/municipality/annual_report09-

10/final/ar0910_part2ch2_pg42-48.pdf

6. Buffalo City Metropolitan Municipality. (2011). Service Delivery and Budget Implementation Plan for 2011/2012. Buffalo City Metropolitan Municipality. Executive Directorate: Strategic Management. Retrieved from: http://www.google.co.uk/\#hl=en\&sclient=psy-...

7. Buffalo City Metropolitan Municipality. (2012). Vacancies. Retrieved from: http://www.buffalocity.gov.za/municipality/vacancies2012/vacancies_12march12.pdf 
8. Castellano, J.F., Young, S., \& Roehm, H.A. (2004). The seven fatal flaws of performance management. The CPA Journal, 74(6): 32-35. Retrieved from: http://www.nysscpa.org/cpajournal/2004/604/essentials/p32.htm

9. Churchill, G.A., Ford, N.M., \& Walker, O.C. (1990). Sales force management: Planning, implementation and control. Boston: Irwin.

10. Coetzer, P. (2009). Service delivery falls prey to political expediency: Minister to put a turnaround strategy on the table. Retrieved from: http://www.servicepublication.co.za/index.php/magazine/other/175-servicedelivery-falls-prey-to-political-expediency

11. Cottom, D. (2003). Why education is useless. Pennsylvania: University of Pennsylvania Press.

12. Council of UC Staff Assemblies. (2011). Performance Management Workgroup Report. Retrieved from: http://www.ucop.edu/cucsa/documents/performance-management2012.pdf

13. Creswell, J. W., \& Plano-Clark, V. L. (2007). Designing and constructing mixed research methods. London: Thousand Oaks.

14. DeCenzo, D.A., \& Robbins, S.P. (2005). Fundamentals of human resource management. New York: John Wiley \& Sons.

15. De Kock, R. (2012). Damning AG report on East Cape municipalities. Retrieved from: http://www.peherald.com/news/article/7525

16. Dixon, R. (2004). The management task. New York: Esevier Butterworth-Heinemann.

17. Faling, C. (2011). The service delivery dilemma: Skills shortage or poor work ethic. Skills universe. Retrieved from: http://www.skills-universe.com/profiles/blogs/the-service-delivery-dilemma

18. Gourrah, S. (2011). Buffalo City Municipality state of infrastructure: A municipal perspective. Retrieved from: http://www.infrastructuredialogues.co.za/wp-content/uploads/2012/10/ID14SyGourrah.pdf

19. Hale, J. (2004). Performance-based management: What every manager should do to get results. San Francisco: John Wiley \& Sons Ltd.

20. Holloway, J. (2009). Performance management from multiple perspectives: Taking stock. International Journal of Productivity and Performance Management, 58(4): 391-399.

21. Johnson, S. (2005). The pyramids and pitfalls of performance measurement. Retrieved from: http://www.accaglobal.com/us/en/student/acca-qual-student-journey/

22. Kaseke, L. L. (2011). Challenges facing the Limpopo Department of Public Works with regard to service delivery: A case of the core functions of the Department. Limpopo, South Africa: University of Limpopo.

23. Kates, J., Marconi, K., \& Mannle Jr., T.E. (2001). Developing a performance management system for a federal public health programme: The Ryan White Care Act Titles I and II. Evaluation and Programme Planning, 24, 145-155. Retrieved from: http://dx.doi.org/10.1016/S0149-7189(01)00005-2

24. Krapohl, J. (2007). Assessing management competencies in selected Southern Cape municipalities. Unpublished MA dissertation. Port Elizabeth, South Africa: Nelson Mandela Metropolitan University. Retrieved from: http://www.nmmu.ac.za/documents/theses/THESIS-28-11-2007.pdf

25. Kwinana, T.J. (2010). A study of the competencies and skills required by senior municipal managers in the O.R. Tambo District Municipality. Unpublished MA dissertation. Port Elizabeth, South Africa: Nelson Mandela Metropolitan University. Retrieved from: http://www.nmmu.ac.za/documents/theses/Jimmy\%20Thozamile\%20Kwinana.pdf

26. Malim, M.R., \& Halim, F.A. (2011). Business statistics. Selangor Darul Ehsan, Malaysia: Oxford.

27. Mawonga, T. A. (2012). A critical analysis of the applicability of the King III in the local government sphere: A case of the Buffalo City Metropolitan Municipality in the Eastern Cape from 2009-2011. Unpublished MA dissertation. Alice, South Africa: University of Fort Hare.

28. Mokone, T., \& De Kock, R. (2014). The Herald, 31 July 2014.

29. Mntengwana, T. (2013). Mayoral bursaries for students. Buffalo City Metro. Retrieved from: http://www.buffalocity.gov.za/news2013/feb/feb6_bursary.stm

30. New Age. (2011). Officials arrested for fraud and corruption. Retrieved from: http://www.thenewage.co.za/24998-1016-53-Officials_arrested_for_fraud_and_corruption

31. Nini, A. (2012a). AG blames political leaders. Retrieved from: http://www.dispatch.co.za/news/article/3190

32. Nini, A. (2012b). BCM's R1.4 bn audit disgrace. Retrieved from: http://www.dispatch.co.za/news/article/2744 
33. Nombembe, T. (2011). Municipalities' misuse of money rockets. Retrieved from: http://www.fin24.com/Economy/Municipalities-misuse-of-money-rockets-20110630

34. Nombembe, T. (2013). Consolidated general report on the audit outcomes of Local Government 2011-12. Auditor-General. Pretoria.

35. Ochurub, M., Bussin, M., \& Goosen, X. (2012). Organisational readiness for introducing a performance management system. SA Journal of Human Resource Management/ SA Tydskrif vir Menslikehulpbronbestuur, 10(1), Art. \#389, 11 pages. Retrieved from: http://dx.doi.org/10.4102/ sajhrm.v10i1.389

36. Olve, N., Roy, J., \& Wetter, M. (2004). A practical guide to the balanced scorecard: Performance drivers. London: Wiley \& Sons Ltd.

37. Overstrand Municipality. (2008). Performance management system: Implementation policy. Johannesburg: Pro-active Management Services.

38. Poister, T.H. (2003). Measuring performance in public and non-profit organisations. San Francisco: Jossey-Bass.

39. Pun, K.F., \& White, A.S. (2005). A performance measurement paradigm for integrating strategy formulation: A review of systems and frameworks. International Journal of Management Reviews, 7(1): 49-71.

40. Rotundo, M. (2002). Defining and measuring individual level job performance: A review and integration. Joseph L. Rotman School of Management University of Toronto. Retrieved from: http://citeseerx.ist.psu.edu/viewdoc/download?doi=10.1.1.129.7597\&rep=rep1\&type=pdf

41. Singh, P., \& Twalo, T. (2014). Impact of human factors on the labour process: A case study. International Business \& Economics Research Journal, 13(2): 305-318.

42. Stokes, G. (2010). South Africa Inc laments skills shortage. . Retrieved from: http://www.fanews.co.za/article.asp?Front_Page_Features 25,Straight_Talk 1146,South_Africa_Inc_lame nts_skills_shortage 7443

43. The Constitution of South Africa. (2011). Section 153. Retrieved from: http://localgovernmentaction.org.dedi6.cpt3.host-h.net/content/constitution-south-africa

44. Times Live. (2011). We're paying dearly for ANC's cadre deployment policy. Retrieved from: http://www.timeslive.co.za/opinion/editorials/2011/12/08/we-re-paying-dearly-for-anc-s-cadredeployment-policy

45. Times Live. (2012). Reality check on services. Retrieved from: http://www.timeslive.co.za/thetimes/2012/07/24/reality-check-on-services

46. Twalo, T.G. (2014). Appropriateness of municipal workers' job behaviour and performance at the Buffalo City Metropolitan Municipality (Unpublished PhD thesis). Port Elizabeth: Nelson Mandela Metropolitan University.

47. US Department of Commerce. (2014). Performance management system definitions. Retrieved from: http://hr.commerce.gov/Practitioners/CompensationAndLeave/DEV01_006178

48. Watts, T., \& McNair-Connolly, C.J. (2012). New performance measurement and management control systems. Journal of Applied Accounting Research, 13(3): 226-241.

49. Web Finance. (2013). Business dictionary. Retrieved from: http://www.businessdictionary.com/definition/job-performance.html

50. Williams, R. (1998). Performance Management. London: International Thomson Business Press. 